\title{
Low-Carbon Ti-Mo Microalloyed Hot Rolled Steels: Special Features of the Formation of the Structural State and Mechanical Properties
}

\author{
Alexander Zaitsev ${ }^{1}$ and Nataliya Arutyunyan ${ }^{2, *}$ \\ 1 Bardin Central Research Institute of Ferrous Metallurgy, 105005 Moscow, Russia; aizaitsev1@yandex.ru \\ 2 Faculty of Chemistry, Lomonosov Moscow State University, 119991 Moscow, Russia \\ * Correspondence: naarutyunyan@gmail.com; Tel.: +7-495-939-1673
}

Citation: Zaitsev, A.; Arutyunyan, N. Low-Carbon Ti-Mo Microalloyed Hot Rolled Steels: Special Features of the Formation of the Structural State and Mechanical Properties. Metals 2021, 11, 1584. https://doi.org/10.3390/ met11101584

Academic Editor: Andre

Paulo Tschiptschin

Received: 20 August 2021

Accepted: 2 October 2021

Published: 5 October 2021

Publisher's Note: MDPI stays neutral with regard to jurisdictional claims in published maps and institutional affiliations.

Copyright: (c) 2021 by the authors. Licensee MDPI, Basel, Switzerland. This article is an open access article distributed under the terms and conditions of the Creative Commons Attribution (CC BY) license (https:/ / creativecommons.org/licenses/by/ $4.0 /)$.

\begin{abstract}
Low-carbon Ti-Mo microalloyed steels represent a new generation of high strength steels for automobile sheet. Excellent indicators of difficult-to-combine technological, strength, and other service properties are achieved due to the superposition of a dispersed ferrite matrix and a bulk system of nanoscale carbide precipitates. Recently, developments are underway to optimize thermodeformation processing for the most efficient use of phase precipitates. The review summarizes and analyzes the results of studies of mechanical properties depending on the chemical composition and parameters of hot deformation of low-carbon Ti-Mo microalloyed steels. Particular attention is paid to the features of the formation and the influence of various types of phase precipitates and the dispersion of the microstructure on mechanical properties. The advantages of Ti-Mo microalloying system and the tasks requiring further solution are shown.
\end{abstract}

Keywords: Ti-Mo microalloyed steels; low-carbon steels; grain boundary strengthening; precipitation strengthening; interphase precipitates; ferritic precipitates; (Ti, Mo)C complex carbide; thermodeformation treatment; hot rolling parameters

\section{Introduction}

At present, one of the areas with the highest priority in the development of world science and technology, is the problem of creating a new generation of various types of structural steels (first of all, for automobile sheets, pipes) with a fundamentally improved complex of difficult-to-combine indicators of strength, ductility, formability, corrosion resistance, operational reliability, and other service properties, while reducing production costs. This is due to the high rates of both production volume and the importance of such materials for the strategic, technical, economic, environmental, and social development of the world. One of the promising areas of research and development within the framework of the formulated problem is the creation of new high-strength low-carbon microalloyed steels with a homogeneous dispersed ferrite matrix. Due to the low carbon concentration, ferritic steels have good weldability, corrosion resistance, and other service properties. High strength is achieved due to the creation of a volumetric system of various types of phase precipitates and dispersed microstructure that leads to grain boundary and precipitation strengthening. The successful use of the contribution of nanoscale precipitates to the strengthening Ti-Mo microalloyed steels has allowed the development of steels with a tensile strength of $780 \mathrm{MPa}$ [1], which are named NANOHITEN and are produced by JFE Steel.

These steels have received special attention in a number of recent detailed reviews on advanced high-strength steels [2], microalloyed steels [3], and Ti-microalloyed steels [4,5].

In [2], NANOHITEN-type ferritic steels, reinforced with nanoscale precipitates, are referred to the third generation of advanced high strength steels. The review substantiates the relevance of the development of these steels in the face of constant demand 
for high-performance lightweight materials in the automotive and other manufacturing industries. It is shown that the priority tasks for this are the optimization of the parameters of thermo-deformation processing, which are close to manufacture conditions, on the basis of researches, including the determination of the relationship between processing, microstructure, and mechanical properties.

Review [3] summarizes the main changes in the chemical composition, processing technologies, and the evolution of mechanical properties in recent years of microalloying high-strength steels. Particular attention is paid to the effect of hydrogen and studies of the mechanisms of hydrogen embrittlement in these steels.

In [4], new aspects of the role of titanium in the development of microalloyed steels, including for pipelines, are considered. Information is presented on the physical state of titanium and its compounds, which are characteristic for microalloyed steels, the morphology and solubility in iron of the precipitates formed, and their effect on the formation of the microstructure of bainite/acicular ferrite and mechanical properties. Particular attention is paid to the effect of titanium microalloying on hot ductility and thin slab direct-charging process.

Review [5] discusses the economic benefits of titanium microalloyed high-strength steels (with different compositions and strength levels) for widespread use in a variety of industries. Characteristics of titanium precipitates are discussed. It is concluded that one of the unresolved key tasks is the control of the precipitation of nanoscale carbides for the most efficient use of titanium in steel.

Therefore, the improvement of Ti-Mo microalloyed steels is currently underway. At the same time, intensive researches are aimed to finding the possibility of purposeful formation of the most optimal structural state, including determining the role and patterns of the formation of phase precipitates at various stages of thermo-deformation processing of steel. Precipitates formed during hot deformation in austenite (so-called "austenitic" precipitates) are influencing on the dispersion of the microstructure. Precipitates formed as a result of random nucleation and growth in a ferrite matrix (so-called "ferritic" precipitates) contribute to precipitation strengthening. During the $\gamma \rightarrow \alpha$ phase transformation of steel, the so-called interphase precipitates are formed. They are arranged in layers parallel to the moving front of the $\gamma / \alpha$ transformation [6]. It is essential that interphase precipitates increase the strength of the steel not only by the precipitation strengthening mechanism, but also contribute to the formation of a fine-grained structure by inhibiting grain growth.

Since the interest in low-carbon Ti-Mo microalloyed steels continues, it is important to systematize and summarize the available information, including the results achieved, in order to improve the understanding of further ways and directions of developing these materials. In contrast to the available reviews, including [2-5], this article is devoted specifically to low-carbon Ti-Mo microalloyed steels. In this case, special attention is paid to the results of studies of the conditions for the formation of a structural state, including a microstructure and different types of phase precipitates, and, as a result, its effect on mechanical properties depending on the chemical composition and parameters of hot deformation. The main part of the review includes the problem of increasing the strength; therefore, the main mechanisms of strengthening, the effect of the chemical composition (primarily, the content of titanium and molybdenum) and the parameters of thermo-deformation processing are considered sequentially. Then the available few results of the impact toughness studies are presented. In conclusion, the open problems that hinder the further development of Ti-Mo microalloyed steels with high mechanical and other service properties are summarized.

\section{Implementation of the Main Strengthening Mechanisms}

\subsection{Grain-Boundary Strengthening}

Grain-boundary strengthening is one of the main factors that determine high strength characteristics of microalloyed steels. The formation of fine grains of ferrite in a number of microalloyed high-strength steels is the result of the formation of ferrite from unrecrystal- 
lized austenite. In this case, due to the high surface area of the grain boundaries of austenite per unit volume, an increase in the nucleation sites of ferrite and a significant refinement of its grain are provided [7]. The main reason that retards (stops) recrystallization of austenite during hot deformation is its inhibition by the "austenitic" phase precipitates formed upon initiation of deformation [8]. Microalloying with niobium most effectively slows down the recrystallization of austenite during hot deformation, but the effect of titanium is also significant [7].

During the process of $\gamma \rightarrow \alpha$-transformation, the final structure of the steel is formed, which is determined by the state of austenite before transformation, the chemical composition and the cooling mode of the steel. The influence of microalloying elements on this process, which is controlled by the diffusion of carbon in austenite, depends on their state: in a solid solution or in a carbonitride phase. Phase precipitates formed in the austenite region are the sites of ferrite nucleation and, thus, contribute to the refinement of the microstructure.

In studies of Ti-Mo microalloyed steels, "austenitic" carbonitride precipitates were not detected [9] or were observed in very small amounts [10]. This led to the intensive formation of interphase precipitates.

According to [11,12], the addition of molybdenum is favorable for the formation of the dispersed ferrite (acicular type) in Ti-Mo microalloyed steels. This is due to the combined effect of impurity inhibition and a decrease in the intensity of carbon diffusion to the interfaces as a result of the strong tendency of molybdenum to form segregations at the interfaces [12].

\subsection{Peculiarities of the Acicular Ferrite Formation}

The microstructure of acicular ferrite (AF) is characterized by a chaotic arrangement of ultra-thin $(2-3 \mu \mathrm{m})$ [4] needle-like ferrite grains (Figure 1). Comparison of the mechanical properties of metal with the microstructure of various types of ferrite, summarized in [13], indicate an increased strength of the AF, including due to the high density of dislocations $\left(10^{6}-10^{8} \mathrm{~mm}^{-2}\right)$, and good impact toughness [14-18].

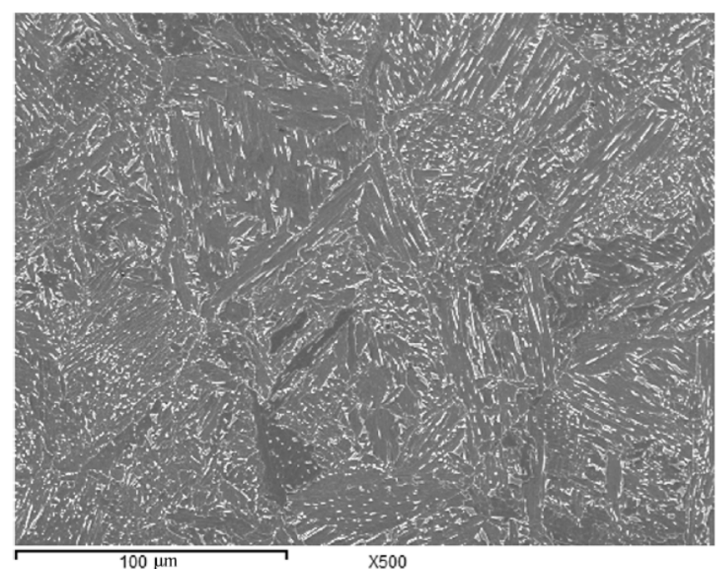

Figure 1. Microstructure of acicular ferrite in steel containing (wt.\%): $0.08 \mathrm{C}-0.21 \mathrm{Mo}-0.165 \mathrm{Ti}$, Reprinted with permission from Ref. [9]. Copyright 2021 Metallurgizdat.

Detailed information and analysis of AF formation is presented in $[4,13,19]$. Despite the fact that the mechanism of the transformation of austenite into AF is identical to the mechanism of formation of the upper bainite microstructure, the places of their nucleation are significantly different. Bainite originates at the boundaries of austenite grains and/or at the active interface between ferrite and austenite, AF plates are generated on nonmetallic inclusions within austenite grains present in the steel matrix $[4,13,19]$. Therefore, a necessary condition for the formation of a finely dispersed structure of the AF type is the 
presence of a certain amount of non-metallic inclusions in the metal. Several mechanisms have been proposed to explain the generation of $\mathrm{AF}$ on non-metallic inclusions:

- A reduction in the interfacial energy for simple heterogeneous nucleation on a surface of inclusions [20-22];

- An epitaxial nucleation on the inclusions, which have a good coherency with ferrite [23];

- A nucleation arising from the thermal strains at the inclusions, which is associated with the different thermal expansion coefficients of the inclusions and steel matrix [24];

- A nucleation arising from solute depletion of elements in the matrix near inclusions [15, 16,25-28].

The implementation of each mechanism depends on the chemical composition of the steel, cooling rate, grain size of austenite, type, size, morphology, and amount of nonmetallic inclusions [13]. For Ti-Mo microalloyed steels, a positive factor is that titaniumcontaining non-metallic inclusions, for example, $\mathrm{Ti}_{2} \mathrm{O}_{3}$ [29], play an essential role for the formation of AF. The heterogeneity and/or complexity of some inclusions (for example, $\mathrm{Ti}_{2} \mathrm{O}_{3}$-based inclusions with the $\mathrm{MnS}$ and TiN formed on them) make it possible to achieve a favorable correspondence between the lattices of the substrate and the incipient phase [13]. For example, in $[23,30]$ it was shown that ferrite grains nucleate inside austenite grains on complex inclusions $\mathrm{Ti}_{2} \mathrm{O}_{3}+\mathrm{TiN}$, $\mathrm{TiN}+\mathrm{MnS}$; however, TiN particles [23] most effectively contribute to the nucleation of AF due to the orientation relation between the phase TiN and ferrite.

Table 1 shows the results of $[13,15,18,23,26,29,31-33]$, which present possible types of non-metallic titanium containing inclusions that promote the nucleation of AF. According to [13], complex inclusions are the most favorable for AF formation. In [33] it was shown that for steels of one grade a certain type of inclusions could be favorable, for another grade- these inclusions are inert. Therefore, the potential of a non-metallic inclusion for nucleation of acicular ferrite has to be always considered and evaluated in accordance with the chemical composition of the steel.

Table 1. Non-metallic titanium containing inclusions favorable for the formation of acicular ferrite.

\begin{tabular}{|c|c|}
\hline Chemical Composition & References \\
\hline $\mathrm{Ti}_{2} \mathrm{O}_{3}$ & {$[26,29]$} \\
\hline $\mathrm{TiO}_{2}$ & [31] \\
\hline $\mathrm{MnTi}_{2} \mathrm{O}_{4}$ & {$[32]$} \\
\hline$(\mathrm{Ti}, \mathrm{Al}) \mathrm{O}_{x}$ & [33] \\
\hline $\mathrm{TiN}$ & [23] \\
\hline $\mathrm{Ti}_{2} \mathrm{O}_{3}-\mathrm{TiN}$ & [23] \\
\hline TiN-MnS & [23] \\
\hline $\mathrm{Ti}_{2} \mathrm{O}_{3}-\mathrm{Al}_{2} \mathrm{O}_{3}-\mathrm{MnS}$ & [18] \\
\hline $\mathrm{TiO}_{x}-\mathrm{TiN}-\mathrm{MnS}$ & [13] \\
\hline Ti- and Ti-Ca- oxy-sulfides & [15] \\
\hline
\end{tabular}

The question of the critical size of inclusions and their volume fraction still remains open. Summarizing the data of various studies, in [19], the critical size of the inclusion is defined as $0.3-1 \mu \mathrm{m}$. According to [13], inclusions larger than $1 \mu \mathrm{m}$ are more likely to nucleate ferrite. However, most AF nuclei in steel have a diameter of $0.5-0.8 \mu \mathrm{m}$. Although the amount of inclusions in steel is considered the main factor in the nucleation of acicular ferrite, only about $10-36 \%$ of the inclusions take part in the nucleation process [13]. Therefore, the vast majority of inclusions do not play any role in the nucleation of ferrite. It was concluded in [33] that the number of inclusions should be large enough to provide sufficient nucleation centers, but as low as possible to meet the requirements for high quality steels. In this case, the type of inclusions for the nucleation of acicular ferrite is more important than the number of effective particles. 


\subsection{Precipitation Strengthening}

The prospects for the development of steels with a high complex of properties due to the implementation of various mechanisms of precipitation strengthening are analyzed and substantiated in the works [34-37]. As shown by the results of studies of ferritic steels containing titanium and molybdenum, including [1,38-42], the amount of precipitation strengthening is significant and increases with a decrease in the size of particles (up to $1-3 \mathrm{~nm}$ ) and an increase in their number.

For example, the contribution to the yield strength of Ti-Mo steels, as shown by estimates, can reach $400 \mathrm{MPa}$ and more [43,44]. At the same time, high strength corresponding to the strength class of $1180 \mathrm{MPa}$ [45] is achieved due to an increase in precipitation strengthening while maintaining practically unchanged contributions corresponding to the basic level of strength of ferritic steels: solid solution hardening and hardening due to refining of ferrite grains.

Figure 2 shows a comparative diagram of the contributions of precipitation strengthening of low-carbon steels of different microalloying systems according to estimates carried out in $[1,38-40,43,44,46]$.

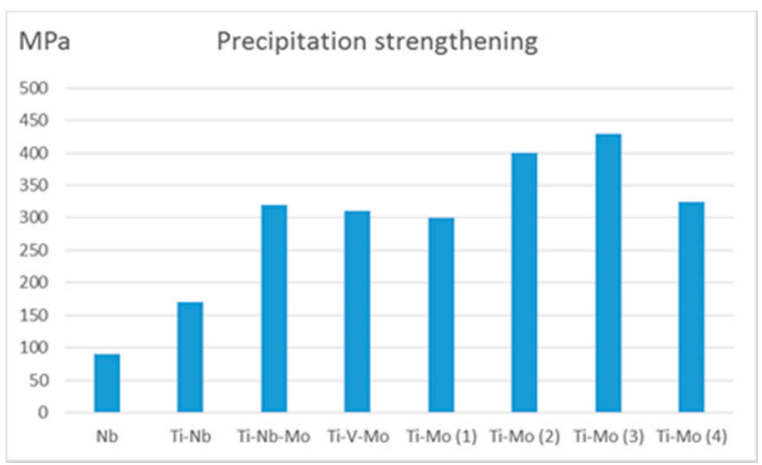

Figure 2. The contribution of precipitation strengthening according to estimates made for low-carbon steels microalloyed with $\mathrm{Nb}$ (Adapted from Ref. [46]), Ti-Nb (Adapted from Ref. [38]), Ti-Nb-Mo (Adapted from Ref. [38]), Ti-Mo-V (Adapted from Ref. [40]), Ti-Mo (1) (Adapted from Ref. [1]), Ti-Mo(2) (Adapted from Ref. [43]), Ti-Mo(3) (Adapted from Ref. [44]), Ti-Mo(4) (Adapted from Ref. [39]).

It should be noted the advantage of precipitation strengthening during microalloying with titanium in comparison with niobium. According to estimates [7], the contribution of nanoscale $\mathrm{NbC}$ precipitates to the hardening of industrial niobium-containing steels is only 80-100 MPa. This conclusion was confirmed by the results of [46-48]. This is most likely due to kinetic constraints. According to the kinetic study results of [49], the formation of carbide, carbonitride precipitates of $\mathrm{Nb}$, even during deformation, is kinetically inhibited (Figure 3). Therefore, it leads to incompleteness of this process during rolling, a decrease in the efficiency of using $\mathrm{Nb}$ and the level of obtained properties of steel [49].

Analysis of nanoscale carbide precipitates in low-carbon microalloyed steels shows that, as a rule, they are of the "ferritic" and/or interphase type [38,39,46-48,50-53].

Interphase precipitates nucleate at the $\alpha / \gamma$ interface. This was shown in [54] for vanadium carbonitrides, as a consequence of the fact that while there are three possible Baker-Nutting orientation relationships for VCN with ferrite: $(001)_{\alpha} / /(001)_{\mathrm{VC}}$; $(010)_{\alpha} / /(110)_{\mathrm{VC}} ;(100)_{\alpha} / /(110)_{\mathrm{VC}}$, only one is realized for the interphase precipitates, namely, $(001)_{\alpha} / /(001)_{\mathrm{VC}}$. Since ferrite and austenite are interconnected by the KurdyumovSachs orientation relation: $(111)_{\gamma} / /(110)_{\alpha}$, then with the selected $(001)_{\alpha} / /(001)_{\mathrm{VC}}$ option the close-packed planes of all three phases turn out to be parallel. This provides the minimum nucleation energy. In addition, it can be assumed that since the chemical driving force is sufficiently low at relatively high temperatures, the interface is the energetically preferred place for nucleation. At low temperatures, when the driving force is higher, a 
general precipitation in the ferrite is to be expected. In the works $[47,48]$, it is shown that a prerequisite for the formation of interphase precipitates is the balance between the growth rate of ferrite and the supersaturation of the solid solution relative to the excessive phase. In this case, low growth rates of ferrite grains and high supersaturation are preferred.

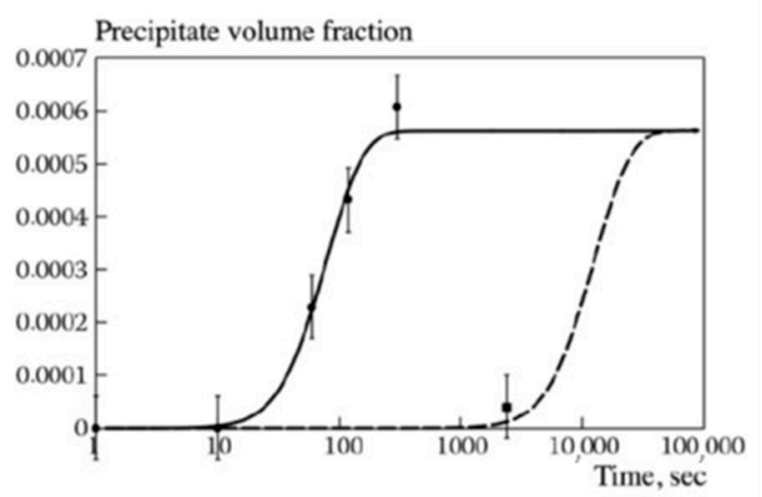

Figure 3. Isothermal diagram of niobium carbonitride precipitation rate at $900{ }^{\circ} \mathrm{C}$. Pointsexperimental data, lines—calculation results: solid—with deformation, dashed-without deformation Reprinted with permission from Ref. [49]. Copyright 2021 Metallurgizdat.

According to estimates based on the results of electron microscopy studies $[1,38,43,45]$, the high contribution of precipitation strengthening (Figure 2) can only be due to interphase precipitates.

At the same time, the presence of random particles precipitated in the ferrite matrix also contributes to the strengthening [50].

The formation of interphase precipitates occurs during the $\gamma \rightarrow \alpha$ transformation, they have a size of 3-10 $\mathrm{nm}$ and make up layers with a period of 10-20 nm (Figure 4). If, after cooling to the temperature of coiling the hot-rolled strip into a coil, the ferrite matrix remains supersaturated with microalloying elements, then during the subsequent relatively slow cooling, the precipitation of nanoscale carbides occurs. The arrangement of these particles is not ordered, as in the case of interphase precipitates [38,55]. The nucleation and growth of disordered nanoscale carbides in ferrite occurs on dislocations, their average size is $3-10 \mathrm{~nm}$ [38].

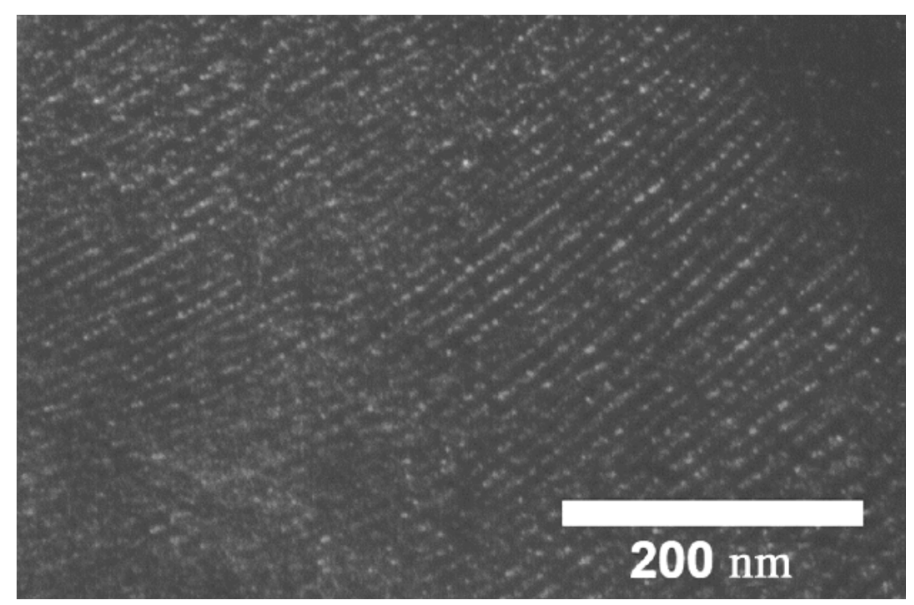

Figure 4. Interphase precipitates in steel containing (wt.\%): 0.08C-0.21Mo-0.165Ti Reprinted with permission from Ref. [9]. Copyright 2021 Metallurgizdat. 


\section{Influence of Chemical Composition}

\subsection{Strengthening Effect Due to (Ti, Mo)C Carbide Precipitation}

Active studies of the possibility of achieving high strength properties of low-carbon microalloyed steels indicate that due to alloying with molybdenum in steels with various basic microalloying components and their combinations, the ultimate strength can be increased up to $800-1000 \mathrm{MPa}[1,35,36,38-40,56,57]$. In this case, the strengthening effect, mainly achieved due to the precipitation of nanoscale molybdenum-containing carbides, is estimated at 300-400 MPa (Figure 2).

The chemical composition of ( $\mathrm{Ti}, \mathrm{Mo}) \mathrm{C}$ carbides depends on the duration (holding) of their precipitation and, accordingly, the size [50,58]. Ti/Mo atomic ratio in (Ti, Mo)C carbide in Ti-Nb-Mo steel after different isothermal holding intervals of 3 and $180 \mathrm{~min}$. changed from 63:37 to 82:18 [50]. The latter value is in good agreement with the data of [41], in which (Ti, Mo)C precipitates found in Ti-Mo steel subjected to isothermal holding for 1 $\mathrm{h}$ contained $\mathrm{Ti}$ and $\mathrm{Mo}$ in an atomic ratio $\mathrm{Ti} / \mathrm{Mo} \sim$ 80:20.

A decrease in the size of carbides with the addition of molybdenum to steel microalloyed with titanium $[40,59]$ and $\mathrm{Ti}-\mathrm{Nb}[38,41,60]$ has been established. The addition of molybdenum to steel increases the rate of carbide nucleation. As a result, the distance between the rows of $(\mathrm{Ti}, \mathrm{Mo}) \mathrm{C}$ and $(\mathrm{Ti}, \mathrm{Nb}, \mathrm{Mo}) \mathrm{C}$ precipitates and the size of the carbide precipitates themselves are significantly reduced. Analysis of the precipitation of the carbide containing molybdenum involves consideration of two competitive processes. On the one hand, the substitution of molybdenum for titanium and niobium in carbide is constrained by the increase in Gibbs free energy. On the other hand, the incorporation of molybdenum into the carbide reduces the degree of lattice mismatch between the carbide and the matrix due to a decrease in the lattice period, and, consequently, the energy of the carbide/austenite interface [61]. The second effect is more pronounced during the initial stage of precipitation when carbide particles are relatively small and, therefore, their precipitation is accelerated by the addition of Mo. Smaller particles (Ti, Mo)C contain a higher fraction of Mo, as was found in [50].

In addition, it was found that Mo atoms tend to be in the outer region of complex carbide precipitates at an early stage of precipitation, which leads to a stronger decrease in the energy of the interface [62]. Since the surface-to-volume ratio decreases with increasing particle size, the volume fraction of Mo enrichment decreases, which leads to a decrease in the Mo fraction in carbide precipitates with increasing time [50,58].

The possibility of the formation of a system of nanoscale precipitates, coherent with the matrix, is due to their high nucleation rate, but low growth rate, which gives them thermal stability $[41,44,50,57,58,63]$. The study of the change in the particle size of (Ti, Mo)C in steel microalloyed with titanium and molybdenum, and TiC in steel microalloyed with titanium during isothermal holding at $925^{\circ} \mathrm{C}$ for various durations was carried out in [63]. It was shown that, at the initial stage of precipitation, carbides in both steel grow very quickly with almost the same value in growth rate. With the increase of holding time, the growth rate of carbides slowed down for both steel. However, the size of (Ti, Mo)C particles in Ti-Mo steel was almost unchanged from $200 \mathrm{~s}$ to $1800 \mathrm{~s}$. Thus, (Ti, Mo)C particles in Ti-Mo-microalloyed steel had a smaller size and higher density than TiC particles in steel alloyed with titanium only. Similar results were obtained for $\mathrm{Nb}$-microalloyed [57] and Ti-Nb -microalloyed steels [50].

According to $[57,64]$, the thermal stability of Mo-containing carbides is associated with diffusion processes. For the growth of Mo-containing precipitates, diffusion of Mo and other microalloying elements from the ferrite matrix to the ferrite/carbide interface is required. Since the diffusion rate of Mo is lower than that of other microalloying elements, the growth rate of precipitates is controlled by the diffusion of Mo and therefore slows down [64]. In [65], it is said that the Oswald ripening of Ti-containing carbides is controlled by titanium diffusion and is suppressed by reducing the solution of titanium. 


\subsection{Influence of Titanium Content}

Table 2 summarizes information on the mechanical properties of various studied Ti-Mo microalloyed steels and the corresponding parameters of hot rolling: finishing temperature of rolling $\left(T_{f}\right)$ and coiling temperature $\left(T_{c}\right)$, as well as the cooling rate from $T_{f}$ to $T_{c}\left(V_{c}\right)$. For the compositions studied in $[9,10,39,65-67]$, the values of $T_{f}$ and $T_{c}$ corresponding to the highest tensile and yield strengths were selected. It can be seen that the titanium content is from 0.09 to $0.233 \mathrm{wt} . \%$, and molybdenum is usually $0.19-0.22 \mathrm{wt} . \%$, in some cases up to 0.43 wt. \%.

Table 2. Chemical composition, hot rolling parameters, and mechanical properties of low-carbon Ti-Mo microalloyed steels.

\begin{tabular}{|c|c|c|c|c|c|c|c|c|c|c|c|c|c|c|c|c|c|c|}
\hline \multirow{2}{*}{ No. } & \multicolumn{11}{|c|}{ Chemical Composition } & \multicolumn{3}{|c|}{$\begin{array}{l}\text { Hot Rolling } \\
\text { Parameters }\end{array}$} & \multicolumn{3}{|c|}{$\begin{array}{l}\text { Mechanical } \\
\text { Properties }\end{array}$} & \multirow{2}{*}{ Ref. } \\
\hline & C & $\mathrm{Si}$ & Mn & Mo & $\mathrm{Ti}$ & $\mathrm{Cr}$ & $\mathrm{Ni}$ & Al & $\mathbf{P}$ & $S$ & $\mathbf{N}$ & ${ }^{T_{f}} \mathrm{C}$ & ${ }^{\mathrm{T}_{\mathrm{c}}{ }^{\circ} \mathrm{C}}$ & $\begin{array}{l}\mathrm{V}_{\mathrm{c}} \\
{ }^{\circ} \mathrm{C} / \mathrm{c}\end{array}$ & $\begin{array}{l}\sigma_{0.2} \\
\mathrm{MPa}\end{array}$ & $\begin{array}{r}\sigma_{B}, \\
\text { MPa }\end{array}$ & $\begin{array}{l}\mathcal{\delta} \\
\%\end{array}$ & \\
\hline 1 & 0.043 & 0.18 & 1.62 & 0.19 & 0.092 & - & - & - & 0.008 & 0.001 & 0.0032 & 900 & 620 & 10 & $\sim 780$ & $\sim 800$ & $\sim 23$ & \multirow{2}{*}[1]{} \\
\hline 2 & 0.045 & 0.19 & 1.53 & 0.20 & 0.119 & - & - & - & 0.009 & 0.001 & 0.0031 & 900 & 620 & 10 & $\sim 780$ & $\sim 820$ & $\sim 18$ & \\
\hline 3 & 0.046 & & 1.30 & 0.19 & 0.099 & & & 0.042 & & 0.001 & 0.0028 & 950 & 600 & 10 & 683 & 786 & & [65] \\
\hline 4 & 0.07 & 0.32 & 1.34 & 0.2 & 0.09 & & & 0.04 & & & & 900 & $\begin{array}{l}650 \\
500\end{array}$ & 10 & 642 & 770 & 16.6 & [42] \\
\hline 5 & 0.079 & 0.17 & 1.22 & 0.43 & 0.19 & & & 0.03 & 0.0038 & 0.0052 & 0.0048 & 870 & 600 & $\sim 30$ & 912 & 971 & 16 & [39] \\
\hline 6 & 0.048 & 0.20 & 1.61 & 0.20 & 0.09 & & & 0.02 & 0.020 & 0.006 & 0.0040 & 900 & 650 & 15 & 747 & 807 & 27 & [68] \\
\hline 7 & 0.059 & 0.30 & 1.490 & 0.193 & 0.233 & & & & & & & 900 & 500 & 10 & 858 & 941 & & [41] \\
\hline 8 & 0.075 & 0.20 & 1.75 & 0.275 & 0.17 & 0.16 & 0.175 & 0.035 & & & 0.005 & 880 & 620 & 20 & 860 & 951 & 23.5 & [66] \\
\hline \multirow{2}{*}{9} & \multirow{2}{*}{0.070} & \multirow{2}{*}{0.030} & \multirow{2}{*}{1.64} & \multirow{2}{*}{0.22} & \multirow{2}{*}{0.090} & \multirow{2}{*}{0.050} & \multirow{2}{*}{0.04} & \multirow{2}{*}{0.030} & \multirow{2}{*}{0.008} & \multirow{2}{*}{0.006} & \multirow{2}{*}{0.009} & 870 & 600 & 11 & 649 & 771 & 19.5 & \\
\hline & & & & & & & & & & & & 900 & 620 & 28 & 717 & 767 & 15 & \\
\hline \multirow{2}{*}{10} & \multirow{2}{*}{0.063} & \multirow{2}{*}{0.063} & \multirow{2}{*}{1.61} & \multirow{2}{*}{0.21} & \multirow{2}{*}{0.096} & \multirow{2}{*}{0.021} & \multirow{2}{*}{0.01} & \multirow{2}{*}{0.057} & \multirow{2}{*}{0.003} & \multirow{2}{*}{0.003} & \multirow{2}{*}{0.003} & 850 & 650 & 8 & 694 & 777 & 19.6 & [10] \\
\hline & & & & & & & & & & & & 910 & 620 & 23 & 725 & 780 & 16.5 & \\
\hline 11 & 0.052 & 0.05 & 1.51 & 0.17 & 0.12 & & & 0.053 & 0.003 & 0.003 & 0.003 & 890 & 650 & $\sim 20$ & 814 & 897 & 19 & \\
\hline 12 & 0.08 & 0.15 & 124 & 0.21 & 0.092 & 0.03 & 0.01 & 0.11 & 0.003 & 0.005 & 0.010 & 900 & 650 & $10-15$ & 590 & 670 & 17 & \\
\hline 12 & 0.00 & 0.10 & 1.27 & 0.21 & 0.032 & 0.00 & 0.01 & & & & & & 000 & 30 & 720 & 810 & & 567 \\
\hline 13 & 008 & 016 & 139 & 021 & 0165 & $0 \Omega 3$ & م 01 & 013 & 0003 & 0005 & $0 \cap 00$ & 900 & 650 & $10-15$ & 770 & 840 & 15 & {$[07]$} \\
\hline 10 & 0.00 & 0.10 & (1.0 & 0.21 & 0.100 & 0.00 & 0.01 & 0.10 & 0.000 & 0.000 & 0.007 & 年 & 00 & 30 & 890 & 950 & & \\
\hline
\end{tabular}

The effect of titanium content on the mechanical properties of hot rolled low-carbon molybdenum alloyed steels was investigated in [1]. It was shown that with an increase in the titanium content to $0.09 \mathrm{wt} . \%$, the tensile and yield strengths of steel containing $0.2 \mathrm{wt} . \%$ Mo increases and exceeds $800 \mathrm{MPa}$ and $700 \mathrm{MPa}$, respectively. In addition, the ratio of titanium and molybdenum concentrations is important [1,69], and the maximum values of strength characteristics are achieved when atomic concentrations are equal. In [67] it was also found that steel with a higher titanium content (wt.\%): $0.08 \mathrm{C}-0.21 \mathrm{Mo}-0.165 \mathrm{Ti}$, has higher yield and tensile strengths than steel 0.08C-0.21Mo -0.092Ti (Table 2).

In [10], a theoretical analysis was carried out for the kinetics of TiC precipitation from austenite at 900 and $850{ }^{\circ} \mathrm{C}$ for two steels (Table 2) differing in titanium content (wt.\%): 0.070C-0.22Mo-0.090Ti (No. 9) and 0.063C-0.21Mo-00.096Ti (No. 10). Figure 5 shows that the precipitation of titanium carbide in steel No. 10 is more intensive. This may be caused by an increase in the rate of nucleation and growth due to the more intense delivery of the rate-limiting titanium precipitation reaction to the nucleation sites and to the particles already available for their growth. At the same time, it follows from the kinetic curves (Figure 5) that the reaction of titanium carbide precipitation, especially at high finishing rolling temperatures, will be far from complete. Therefore, in these rolled steels, a sufficiently high concentration of titanium will be retained for further $\mathrm{TiC}$ precipitation in ferrite and/or for the implementation of the mechanism of interphase precipitation. The presence of nanoscale carbide precipitates of all three indicated types in the samples of the 
steels under consideration after hot rolling was confirmed by the methods of transmission electron microscopy (TEM).

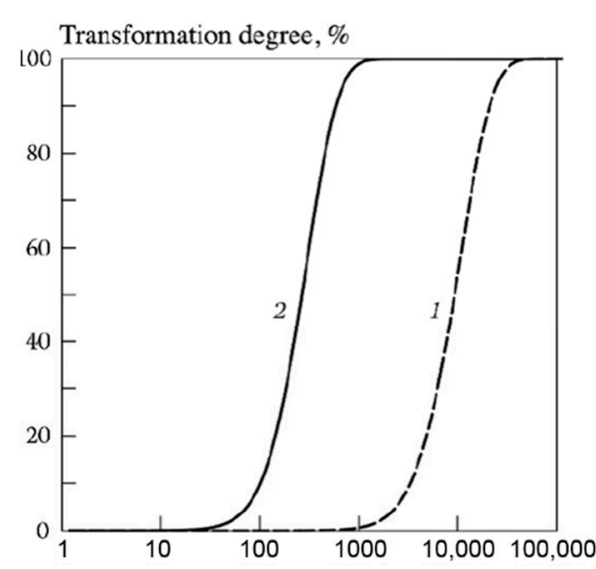

(a)

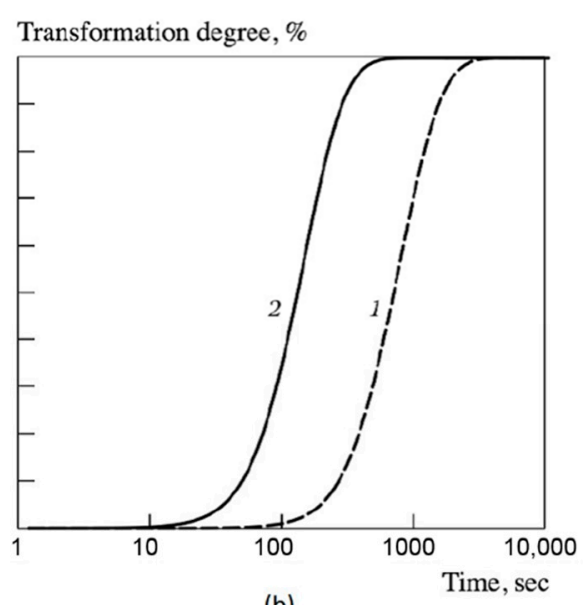

(b)

Figure 5. Isothermal diagram for titanium carbide precipitation at $900{ }^{\circ} \mathrm{C}$ (a) and $850{ }^{\circ} \mathrm{C}(\mathbf{b})$ : 1 steel No. 9, 2-steel No. 10 (Table 2) Reprinted with permission from Ref. [10]. Copyright 2021 Metallurgizdat.

\section{Influence of Thermo-Deformation Parameters}

\subsection{Influence of Temperatures of the Rolling End and Coiling}

The cooling process after hot rolling and during coiling of the strip largely controls the main changes in the microstructure of the metal, the transformation of austenite into ferrite, and the formation of phase precipitates. The influence of $T_{f}, T_{c}$, and the cooling rate of rolled products from $\mathrm{T}_{\mathrm{f}}$ to $\mathrm{T}_{\mathrm{c}}$ on the structural state and mechanical properties has been studied in a number of works $[9,10,39,41,65,67]$.

Despite the established regular parabolic form of the dependence of the hardness and yield strength of microalloyed steels on the coiling temperature in the case of titanium [70,71], the dependences for Ti-Mo microalloyed steels are different (Figure 6). In [65], the strength of steel No. 3 (Table 2) practically did not depend on the coiling temperature in the range of $550-650{ }^{\circ} \mathrm{C}$. High values of tensile and yield strengths are due to the presence of a large number of nanoscale interphase precipitates [65]. In $[39,68]$, the studies of steels No. 5 and No. 6 (Table 2), respectively, were carried out varying coiling temperatures after hot rolling from 500 to $700{ }^{\circ} \mathrm{C}$. The maximum tensile and yield strengths were obtained in the case of $\mathrm{T}_{\mathrm{C}}=600{ }^{\circ} \mathrm{C}$ due to the formation of the largest amount of precipitates, including interphase ones, and in $[10,67]-$ in the case of $\mathrm{T}_{\mathrm{C}}=650{ }^{\circ} \mathrm{C}$. The authors of [41] demonstrated the opposite relationship. With a decrease in $\mathrm{T}_{\mathrm{C}}$ from 700 to $500{ }^{\circ} \mathrm{C}$, the values of $\sigma_{0.2}$ and $\sigma_{\mathrm{B}}$ for steel No. 7 (Table 2) increased due to a decrease in the average size of carbide precipitates and, accordingly, a significant increase in the contribution of precipitation strengthening. Most likely, this is due to the fact that precipitates observed in [41] are only "ferritic" and the formation of interphase precipitates under the experimental conditions did not occur.

In [10], the temperatures of the rolling end and coiling of steel No. 9 (Table 2) varied in the ranges of $860-910{ }^{\circ} \mathrm{C}$ and $560-620^{\circ} \mathrm{C}$, respectively. The TEM study showed that when high temperatures of the end of rolling and coiling $\left(\mathrm{T}_{\mathrm{f}}=900^{\circ} \mathrm{C}\right.$ and $\left.\mathrm{T}_{\mathrm{C}}=620^{\circ} \mathrm{C}\right)$ were used, most of the precipitates presented were interphase, while the obtained samples had a finergrained structure and the highest values of tensile and yield strengths. With a decrease in the temperature parameters of rolling and coiling, the relative amount of interphase precipitates decreased, and when using the regime with $\mathrm{T}_{\mathrm{f}}=860{ }^{\circ} \mathrm{C}$ and $\mathrm{T}_{\mathrm{C}}=560{ }^{\circ} \mathrm{C}$, all observed nanoscale carbide precipitates were "ferritic". 
Yield strength, MPA

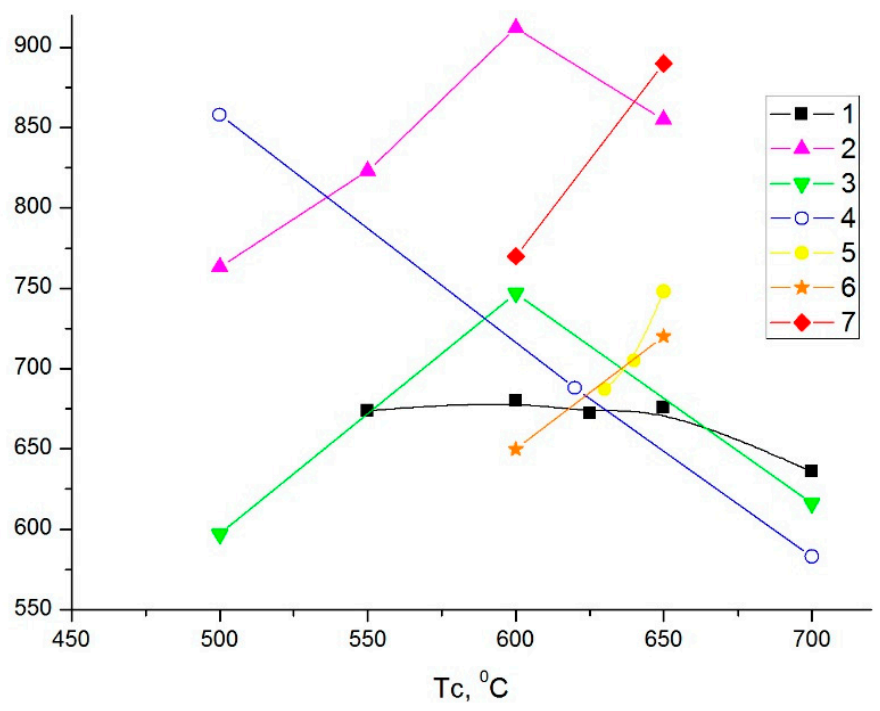

Figure 6. Influence of the coiling temperature on the yield strength of Ti-Mo microalloyed steels (Table 2): 1-No. 3 (Adapted from Ref. [65]), 2-No. 5 (Adapted from Ref. [39]), 3-No. 6 (Adapted from Ref. [68]), 4-No. 7 (Adapted from Ref. [41]), 5-No. 11 (Adapted from Ref. [10]), 6-No. 12 (Adapted from Ref. [67]), 7-No. 13 (Adapted from Ref. [67]).

The authors of [10] explained the favorable effect of increased finishing rolling temperatures on the formation of interphase precipitates by the absence of the formation of carbide (Ti, Mo)C precipitates in the austenite region due to their high solubility. As a result, due to the high concentration of the components in the solid solution, on cooling, the precipitation of carbides occurs during phase transformation. This provides the formation of nanoscale carbide precipitates in the ferrite matrix, which leads to its significant strengthening. The beneficial effect of increased coiling temperatures is associated with an increase in the total amount of nanoscale precipitates, mainly due to an increase in the fraction of precipitates formed during phase transformation. Reducing the coiling temperature leads to suppression of the formation of such precipitates.

The observed fact of the presence of interphase precipitates in steel after rolling with high $T_{f}$ and $T_{c}$ can be explained by a joint analysis of the formation of excessive phase precipitates and the occurrence of $\gamma \rightarrow \alpha$ phase transformation in steel by analogy with the generally accepted approach $[72,73]$. The nucleation of a new layer of particles at the $\gamma / \alpha$ phase boundary occurs when a certain critical concentration of titanium is reached, which is determined from the thermodynamic conditions for the TiC nucleation. When the phase boundary moves, titanium diffuses from it to the nucleated precipitates. This flux of diffusing titanium is compensated by its transition from the $\gamma$ phase through the phase boundary. Thus, the titanium concentration at the moving $\gamma / \alpha$ boundary increases, and the moment when the critical concentration for nucleation is reached determines the distance between the layers. Therefore, the rates of motion of the interface and titanium diffusion, which provides the nucleation and growth of carbide precipitates, should be comparable. On the one hand, an increase in the transformation temperature is more favorable for the implementation of the interphase precipitation mechanism; on the other hand, a decrease in the process temperature decreases the distance between the layers. With a further decrease in temperature, the rate of motion of the interphase boundary turns out to be too high, and after passing through the transformation front, the ferrite remains supersaturated with respect to the excessive phase, which leads to the formation of disordered "ferritic" precipitates. Therefore, there is an optimal temperature range, in which the nucleation and growth of interphase precipitates occurs, but the distance 
between the layers is minimal, which provides the most effective strengthening by the precipitation strengthening mechanism.

This explains the positive effect of an increase in the temperatures of the rolling end and coiling for the studied type of steels on the formation of a larger number of interphase carbide precipitates with a smaller distance between layers and a finer-grained structure and, as a result, its high strength characteristics.

Similar results were obtained in [10] for steel No. 11 (Table 2). When $T_{f}$ and $T_{c}$ were varied in the ranges $860-890^{\circ} \mathrm{C}$ and $630-650{ }^{\circ} \mathrm{C}$, the highest strength values were obtained at $890^{\circ} \mathrm{C}$ and $650^{\circ} \mathrm{C}$, respectively (Table 2), which was accompanied by the formation of a large amount of interphase precipitates (Figure 7). At the same rolling end temperatures (900 and $950^{\circ} \mathrm{C}$ ), the yield and tensile strengths of steels No. 12, 13 (Table 2) were higher in the case of using a coiling temperature of $650{ }^{\circ} \mathrm{C}$ compared to $600^{\circ} \mathrm{C}$ [67]. In this case, the volume fraction of nanoscale interphase and "ferritic" carbide precipitates was also higher.

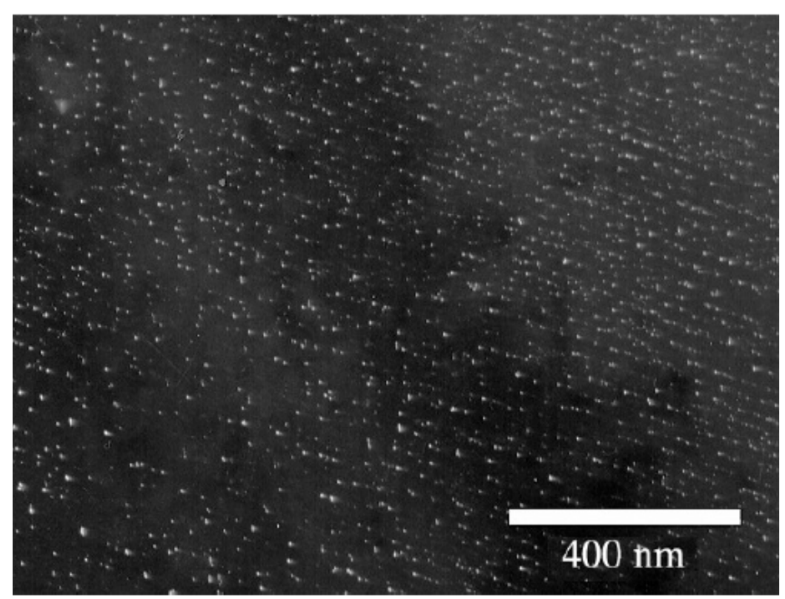

Figure 7. Nanoscale interphase carbide precipitates in rolled steel No. 11 (Table 2) Reprinted with permission from Ref. [10]. Copyright 2021 Metallurgizdat.

\subsection{Influence of the Cooling Rate from $T_{f}$ to $T_{\mathcal{c}}$}

In the works [9,67], the effect of the cooling rate from $T_{f}$ to $T_{c}$ on the formation of the structural state and mechanical properties of steels No. 12, 13 (Table 2) was investigated. Fast cooling was carried out at a rate of $30^{\circ} \mathrm{C} / \mathrm{c}$, slow $-10-15^{\circ} \mathrm{C} / \mathrm{c}$. The results showed that, upon slow cooling, a polygonal ferrite microstructure with a high amount of nanoscale interphase precipitates is formed in steels. With an increase in the cooling rate of the metal after hot rolling, its microstructure is acicular ferrite, which has a higher dislocation density and, as a result, higher strength. However, the formation of nanoscale carbide precipitates in this case occurs in ferrite mainly on dislocations, in the form of randomly spaced individual or small groups of precipitates, instead of the implementation of the mechanism of formation of regularly spaced precipitates during the $\gamma \rightarrow \alpha$ phase transformation of steel, which can lead to a decrease in a number of indicators of its properties. This is due to the fact that the rate of the $\gamma \rightarrow \alpha$ phase transformation of steel turns out to be too high and the formation of precipitates on the moving phase boundary does not have time to occur. Thus, with a change in the cooling rate, opposite tendencies are observed in the implementation of the main strengthening mechanisms.

\section{Impact Toughness}

Recently, the range of technical requirements for high-strength steels has been expanding, and in many cases it includes an additional high level of cold brittleness and low-temperature toughness.

Generally, to avoid significant reduction in toughness, the main approach is to prevent the formation of coarse microstructure and large particles of non-metallic inclusions, usually TiN [74-77]. To increase the impact toughness of low-carbon microalloyed steels, the most 
effective solution is to increase the dispersion of the ferrite microstructure [68]. Comparison of various microalloying systems [68] showed that niobium is most favorable for increasing the impact toughness. For Ti-Mo microalloyed steels, the problem of maintaining good impact toughness at high strength has not yet been solved, which reduces the advantages of this microalloying system.

Results of $[78,79]$ showed a positive effect of low finishing rolling temperature on the impact toughness of microalloyed steels. In [79], the influence of finishing rolling temperature $\left(940,910\right.$, and $\left.880^{\circ} \mathrm{C}\right)$ on the mechanical properties was studied for microalloyed steel with the composition (wt.\%): $0.05 \mathrm{C}-0.22 \mathrm{Si}-1.50 \mathrm{Mn}-0.025 \mathrm{Nb}-0.11 \mathrm{Ti}-0.058 \mathrm{Al}-$ $0.0045 \mathrm{P}-0.0018 \mathrm{~S}-0.004 \mathrm{~N}$. The results showed that with decreasing $\mathrm{T}_{\mathrm{f}}$ both the ferrite grain size and the volume fraction of carbide precipitates decreased, but the size of carbide precipitates changed little. This significantly affected the low temperature impact strength. According to the results of observation of the fracture surface of the samples tested at $-40{ }^{\circ} \mathrm{C}$, the type of fracture of steels with $\mathrm{T}_{\mathrm{f}}=940^{\circ} \mathrm{C}$ and $910{ }^{\circ} \mathrm{C}$ was brittle, and the fracture of steel with $\mathrm{T}_{\mathrm{f}}=880^{\circ} \mathrm{C}$ was ductile. In [78], it was shown that as the finishing rolling temperature of low-carbon steel decreases, the proportion of fine-grained acicular ferrite and, accordingly, the impact toughness increase.

At the same time, the use of low finishing rolling temperature is not always effective for achieving high strength of titanium microalloyed steels, since it prevents the formation of TiC interphase precipitates [9]. Thus, in order to obtain simultaneously high strength and impact toughness of Ti-Mo microalloyed steels, further search for the optimal combination of the content of microalloying elements and the parameters of thermo-deformation processing is necessary for a balanced effect of microstructure characteristics and phase precipitates on the properties of steel.

\section{Conclusions}

The review of studies of low-carbon Ti-Mo microalloyed steels shows the prospects of developments aimed at creating steels of this type with a high complex of technological, mechanical, and other service properties based on the formation of a dispersed structure of acicular ferrite and control of the type, amount and dispersion of carbide precipitates. On the one hand, the regularities of the formation of the structural state and mechanical properties of these steels, depending on the parameters of thermo-deformation treatment, have general tendencies, which are characteristic to ferritic steels of various microalloying systems; on the other hand, they have their own peculiarities.

The presence of titanium-containing non-metallic inclusions in steel contributes to the acicular ferrite nucleation. However, the potential for their effectiveness is not unambiguous, and it has to be always considered and evaluated in accordance with the composition of the steel. An open question is the type, critical size of inclusions and their volume fraction, since a large number of inclusions is a negative factor for the quality of steel.

Due to the goal-oriented selection of the parameters of thermo-deformation processing of steel, it is possible to influence the formation of carbide precipitates of a certain type, amount, and size. The formation of a larger number of interphase precipitates with a smaller distance between the layers, which causes the highest contribution to strengthening, is positively influenced by an increase in the temperatures of the rolling end and coiling. At the same time, for each specific chemical composition, the achievement of maximum strength requires an optimal combination of the temperature of coiling and the rate of cooling of the rolled stock to it after the end of hot rolling of steel. With a slowdown in cooling, the rate of phase transformation decreases, which contributes to the formation of interphase precipitates and, respectively, an increase in the fraction of precipitation strengthening in the strengthening of steel. But under these conditions, the microstructure of acicular ferrite is not formed. Therefore, the question of finding conditions for the formation of an optimal structural state, including the morphological type of ferrite and the characteristics of phase precipitates, providing a high complex of strength and other service properties of steel, is still open. 
Interconnected unsolved problem for Ti-Mo microalloyed steels is to increase the impact toughness while maintaining high strength. Low values of the coiling temperature and increased cooling rates of rolled products, which are favorable for improving the impact toughness of steel, prevent the formation of interphase nanoscale precipitates and reduce strength.

Author Contributions: A.Z. got the idea, directed the project, and reviewed the final version; N.A. wrote the paper. All authors have read and agreed to the published version of the manuscript.

Funding: This work was supported by the grant of the Russian Science Foundation (Project No. 18-19-00639).

Institutional Review Board Statement: Not applicable.

Informed Consent Statement: Not applicable.

Data Availability Statement: Not applicable.

Conflicts of Interest: The authors declare no conflict of interest.

\section{References}

1. Funakawa, Y.; Shiozaki, T.; Tomita, K.; Yamamoto, T.; Maeda, E. Development of high strength hot-rolled sheet steel consisting of ferrite and nanometer-sized carbides. ISIJ Int. 2004, 44, 1945-1951. [CrossRef]

2. Zhao, J.; Jiang, Z. Thermomechanical processing of advanced high strength steels. Prog. Mater Sci. 2018, 94, 174-242. [CrossRef]

3. Villalobos, J.C.; Del-Pozo, A.; Campillo, B.; Mayen, J.; Serna, S. Microalloyed steels through history until 2018: Review of chemical composition, processing and hydrogen service. Metals 2018, 8, 351. [CrossRef]

4. Baker, T.N. Titanium microalloyed steels. Ironmak. Steelmak. 2019, 46, 1-55. [CrossRef]

5. Huo, X.; Xia, J.; Li, L.; Peng, Z.; Chen, S.; Peng, C. A review of research and development on titanium microalloyed high strength steels. Mater. Res. Express. 2018, 5, 062002. [CrossRef]

6. Lagneborg, R.; Siwecki, T.; Zajac, S.; Hutchinson, B. The role of vanadium in microalloyed steels. Scand. J. Metall. 1999, 28, 186-241.

7. DeArdo, A.J. Niobium in modern steels. Int. Mater. Rev. 2003, 48, 371-402. [CrossRef]

8. Jonas, J.J.; Weiss, I. Effect of precipitation on recrystallization in microalloyed steels. Met. Sci. 2013, 13, 238-245. [CrossRef]

9. Koldaev, A.V.; Zaitsev, A.I.; Krasnyanskaya, I.A.; D'yakonov, D.L. Study of the effect of composition and thermal deformation treatment on properties of ferritic steels microalloyed with titanium and niobium. Part 2. Phase precipitate characteristics. Metallurgist 2019, 63, 604-616. [CrossRef]

10. Shaposhnikov, N.G.; Koldaev, A.V.; Zaitsev, A.I.; Rodionova, I.G.; D'yakonov, D.L.; Arutyunyan, N.A. Features of titanium carbide precipitation in low-carbon high-strength steels microalloyed with titanium and molybdenum. Metallurgist 2016, 60, 810-816. [CrossRef]

11. Tang, Z.; Stumpf, W. The role of molybdenum additions and prior deformation on acicular ferrite formation in microalloyed $\mathrm{Nb}-\mathrm{Ti}$ low-carbon line-pipe steels. Mater. Charact. 2008, 59, 717-728. [CrossRef]

12. Xinjun, S. The roles and applications of molybdenum element in low alloy steels. In Proceedings of the International Seminar on Applications Mo in Steels, Beijing, China, 27-28 June 2010. Available online: https://www.imoa.info/download_files/ proceedings/Mo-in-Steels-seminar-proceedings-2010-06_EN.pdf (accessed on 30 September 2021).

13. Sarma, D.S.; Karasev, A.V.; Jonsson, P.G. On role of nonmetallic inclusions in the nucleation of acicular ferrite in steels. ISIJ Int. 2009, 49, 1063-1074. [CrossRef]

14. Farrar, R.A.; Harrison, P.L. Acicular ferrite in carbon-manganese weld metals: An overview. J. Mater. Sci. 1987, 22, 3812-3820. [CrossRef]

15. Lee, J.L.; Pan, Y.T. The formation of intragranular acicular ferrite in simulated heat-affected zone. ISIJ Int. 1995, 35, 1027-1033. [CrossRef]

16. Ohkita, S.; Horii, Y. Recent development in controlling the microstructure and properties of low alloy steel weld metals. ISIJ Int. 1995, 35, 1170-1182. [CrossRef]

17. Xiao, F.R.; Liao, B.; Shan, Y.Y.; Qiao, G.Y.; Zhong, Y.; Zhang, C.; Yang, K. Challenge of mechanical properties of an acicular ferrite pipeline steel. Mater. Sci. Eng. A 2006, 431, 41-52. [CrossRef]

18. Yang, Z.; Wang, F.; Wang, S.; Song, B. Intragranular ferrite formation mechanism and mechanical properties of non-quenchedand-tempered medium carbon steels. Steel Res. Int. 2008, 79, 390-395. [CrossRef]

19. Loder, D.; Michelic, S.K.; Bernhard, C. Acicular ferrite formation and its influencing factors-A review. J. Mater. Sci. Res. 2017, 6, 24-43. [CrossRef]

20. Grong, O.; Kluken, A.O.; Nylund, H.K.; Dons, A.L.; Hjelen, J. Catalyst effects in heterogeneous nucleation of acicular ferrite. Metall. Mater. Trans. A 1995, 26, 525-534. [CrossRef] 
21. Lee, T.K.; Kim, H.J.; Kang, B.Y.; Hwang, S.K. Effect of inclusion size on the nucleation of acicular ferrite in welds. ISIJ Int. 2000, 40, 1260-1268. [CrossRef]

22. Furuhara, T.; Yamaguchi, J.; Sugita, N.; Miyamoto, G.; Maki, T. Nucleation of proeutectoid ferrite on complex precipitates in austenite. ISIJ Int. 2003, 43, 1630-1639. [CrossRef]

23. Jin, H.H.; Shim, J.H.; Ch, Y.W.; Lee, H.C. Formation of intragranular acicular ferrite grains in a Ti-containing low carbon steel. ISIJ Int. 2003, 43, 1111-1113. [CrossRef]

24. Brooksbank, D.; Andrews, K.W. Stress fields around inclusions and their relation to mechanical properties. J. Iron Steel Inst. 1972, $210,246-265$.

25. Mabuchi, H.; Uemori, R.; Fujioka, M. The role of Mn depletion in intra-granular ferrite transformation in the heat affected zone of welded joints with large heat input in structural steels. ISIJ Int. 1996, 36, 1406-1412. [CrossRef]

26. Byun, J.S.; Shim, J.H.; Cho, Y.W.; Lee, D.N. Non-metallic inclusion and intragranular nucleation of ferrite in Ti-killed C-Mn steel. Acta Mater. 2003, 51, 1593-1606. [CrossRef]

27. Shim, J.H.; Oh, Y.J.; Suh, J.Y.; Cho, Y.W.; Shim, J.D.; Byun, J.S.; Lee, D.N. Ferrite nucleation potency of non-metallic inclusions in medium carbon steels. Acta Mater. 2001, 49, 2115-2122. [CrossRef]

28. Liu, Z.; Kobayashi, Y.; Yin, F.; Kuwabara, M.; Nagai, K. Nucleation of acicular ferrite on sulfide inclusion during rapid solidification of low carbon steel. ISIJ Int. 2007, 47, 1781-1788. [CrossRef]

29. Shim, J.H.; Cho, Y.W.; Chung, S.H.; Shim, J.D.; Lee, D.N. Nucleation of intragranular ferrite at $\mathrm{Ti}_{2} \mathrm{O}_{3}$ particle in low carbon steel. Acta Mater. 1999, 47, 2751-2760. [CrossRef]

30. Wang, M.; Cheng, G.; Qiu, S.; Zhao, P.; Gan, Y. Roles of titanium-rich precipitates as inoculants during solidification in low carbon steel. Int. J. Miner. Metall. Mater. 2010, 17, 276-281. [CrossRef]

31. Gregg, J.M.; Bhadeshia, H.K.D.H. Solid-state nucleation of acicular ferrite on minerals added to molten steel. Acta Mater. 1997, 45, 739-748. [CrossRef]

32. Wang, B.; Liu, X.; Wang, G. Inclusion characteristics and acicular ferrite nucleation in Ti-containing weld metals of X80 pipeline steel. Metall. Mater. Trans. A. 2018, 49, 2124-2138. [CrossRef]

33. Loder, D.; Micheli, S.K.; Mayerhofer, A.; Bernhard, C. On the capability of nonmetallic inclusions to act as nuclei for acicular ferrite in different steel grades. Metall. Mater. Trans. B. 2017, 48, 1992-2006. [CrossRef]

34. Kong, H.J.; Liu, C.T. A review on nano-scale precipitation in steels. Technologies 2018, 6, 36. [CrossRef]

35. Kong, H.J.; Xu, C.; Bu, C.C.; Da, C.; Luan, J.H.; Jiao, Z.B.; Chen, G.; Liu, C.T. Hardening mechanisms and impact toughening of a high-strength steel containing low $\mathrm{Ni}$ and $\mathrm{Cu}$ additions. Acta Mater. 2019, 172, 150-160. [CrossRef]

36. Jiang, S.; Wang, H.; Wu, Y.; Liu, X.; Chen, H.; Yao, M.; Gault, B.; Ponge, D.; Raabe, D.; Hirata, A.; et al. Ultrastrong steel via minimal lattice misfit and high-density nanoprecipitation. Nature 2017, 544, 460-464. [CrossRef] [PubMed]

37. Jiao, Z.B.; Luan, J.H.; Miller, M.K.; Chung, Y.W.; Liu, C.T. Co-precipitation of nanoscale particles in steels with ultra-high strength for a new era. Mater. Today 2017, 20, 142-154. [CrossRef]

38. Bu, F.Z.; Wang, X.M.; Yang, S.W.; Shang, C.J.; Misra, R.D.K. Contribution of interphase precipitation on yield strength in thermomechanically simulated Ti-Nb and Ti-Nb-Mo microalloyed steels. Mater. Sci. Eng. A 2014, 620, 22-29. [CrossRef]

39. Zhang, K.; Li, Z.; Wang, Z.; Sun, X.; Yong, Q. Precipitation behavior and mechanical properties of hot-rolled high strength Ti-Mo-bearing ferritic sheet steel: The great potential of nanometer-sized (Ti, Mo)C carbide. J. Mater. Res. 2016, 31, 1254-1263. [CrossRef]

40. Zhang, K.; Li, Z.-D.; Sun, X.-J.; Yong, Q.-L.; Yang, J.-W.; Li, Y.-M.; Zhao, P.-L. Development of Ti-V-Mo complex microalloyed hot-rolled 900-MPa-grade high-strength steel. Acta Metall. Sin. 2015, 28, 641-648. [CrossRef]

41. Park, D.-B.; Huh, M.-Y.; Shim, J.-H.; Suh, J.-Y.; Lee, K.-H.; Jung, W.-S. Strengthening mechanism of hot rolled Ti and Nb microalloyed HSLA steels containing Mo and $\mathrm{W}$ with various coiling temperature. Mater. Sci. Eng. A 2013, 560, 528-534. [CrossRef]

42. Phaniraj, M.P.; Shin, Y.M.; Lee, J.; Goo, N.H.; Kim, D.I.; Suh, J.Y.; Jung, W.S.; Shim, J.H.; Choi, I.S. Development of high strength hot rolled low carbon copper-bearing steel containing nanometer sized carbides. Mater. Sci. Eng. A 2015, 633, 1-8. [CrossRef]

43. Yen, H.W.; Chen, P.Y.; Huang, C.Y.; Yang, J.R. Interphase precipitation of nanometer-sized carbides in a titanium-molybdenumbearing low-carbon steel. Acta Mater. 2011, 59, 6264-6274. [CrossRef]

44. Huang, Y.; Liu, W.; Zhao, A.; Han, J.; Wang, Z.; Yin, H. Effect of Mo content on the thermal stability of Ti-Mo-bearing ferritic steel. Int. J. Miner. Metall. Mater. 2021, 28, 412-421. [CrossRef]

45. Funakawa, Y.; Fujita, T.; Yavada, K. Metallurgical features of NANOHITEN and application to warm stamping. JFE Tech. Rep. 2013, 18, 74-79. Available online: https:/ / www.jfe-steel.co.jp/en/research/report/018/pdf/018-14-2.pdf (accessed on 30 September 2021).

46. Sanz, L.; Pereda, B.; López, B. Effect of thermomechanical treatment and coiling temperature on the strengthening mechanisms of low carbon steels microalloyed with Nb. Mater. Sci. Eng. A 2017, 8, 377-390. [CrossRef]

47. Sakuma, T.; Honeycombe, R.W.K. Microstructures of isothermally transformed Fe-Nb-C alloys. Met. Sci. 1984, 18, 449-454. [CrossRef]

48. Sakuma, T.; Honeycombe, R.W.K. Effect of manganese on microstructure of an isothermally transformed Fe-Nb-C alloy. Mater. Sci. Technol. 1985, 1, 351-356. [CrossRef] 
49. Koldaev, A.V.; D'yakonov, D.L.; Zaitsev, A.I.; Arutyunyan, N.A. Kinetics of the formation of nanosize niobium carbonitride precipitates in low-alloy structural steels. Metallurgist 2017, 60, 1032-1037. [CrossRef]

50. Chen, C.Y.; Chen, C.C.; Yang, J.R. Microstructure characterization of nanometer carbides heterogeneous precipitation in Ti-Nb and Ti-Nb-Mo steel. Mater. Charact. 2014, 88, 69-79. [CrossRef]

51. Lee, W.B.; Hong, S.G.; Park, C.G.; Kim, K.H.; Park, S.H. Influence of Mo on precipitation hardening in hot rolled HSLA steels containing Nb. Scripta Mater. 2000, 43, 319-324. [CrossRef]

52. Zaitsev, A.I.; Rodionova, I.G.; Arutyunyan, N.A.; Dunaev, S.F. Study of features of phase precipitation formation, structural state, and properties of ferritic class microalloyed low-carbon steels. Metallurgist 2020, 64, 750-758. [CrossRef]

53. Zaitsev, A.; Koldaev, A.; Arutyunyan, N.; Dunaev, S.; D'yakonov, D. Effect of the chemical composition on the structural state and mechanical properties of complex microalloyed steels of the ferritic class. Processes 2020, 8, 646. [CrossRef]

54. Khalid, F.A.; Edmonds, D.V. Interphase precipitation in microalloyed engineering steels and model alloy. Mater. Sci. Eng. 1993, 9 , 384-396. [CrossRef]

55. Chen, C.Y.; Yen, H.W.; Kao, F.H.; Li, W.C.; Huang, C.Y.; Yang, J.R.; Wang, S.H. Precipitation hardening of high-strength low-alloy steels by nanometer-sized carbides. Mater. Sci. Eng. A 2009, 499, 162-166. [CrossRef]

56. Jia, Z.; Misra, R.D.K.; O'Malley, R.; Jansto, S.J. Fine-scale precipitation and mechanical properties of thin slab processed titaniumniobium bearing high strength steels. Mater. Sci. Eng. A 2011, 528, 7077-7083. [CrossRef]

57. Zhang, Z.; Yong, Q.; Sun, X.; Li, Z.; Wang, Z.; Zhou, S.; Wang, G. Effect of Mo addition on the precipitation behavior of carbide in Nb-bearing HSLA steel. In HSLA Steels 2015, Microalloying 2015 \& Offshore Engineering Steels 2015; Springer International Publishing: Cham, Switzerland, 2016; pp. 203-210. [CrossRef]

58. Wang, Z.; Zhang, H.; Guo, C.; Liu, W.; Yang, Z.; Sun, X.; Zhang, Z.; Jiang, F. Effect of molybdenum addition on the precipitation of carbides in the austenite matrix of titanium micro-alloyed steels. J. Mater. Sci. 2016, 51, 4996-5007. [CrossRef]

59. Kamikawa, N.; Abe, Y.; Miyamoto, G.; Funakawa, Y.; Furuhara, T. Tensile Behavior of Ti,Mo-added Low Carbon Steels with Interphase Precipitation. ISIJ Int. 2014, 54, 212-221. [CrossRef]

60. Jang, J.; Heo, Y.; Lee, C.; Bhadeshia, H.; Suh, D.-W. Interphase precipitation in Ti-Nb and Ti-Nb-Mo bearing steel. Mater. Sci. Technol. 2013, 29, 309-313. [CrossRef]

61. Jang, J.H.; Lee, C.H.; Heo, Y.U.; Suh, D.W. Stability of (Ti,M)C (M = Nb, V, Mo and W) carbide in steels using first-principles calculations. Acta Mater. 2012, 60, 208-217. [CrossRef]

62. Wang, Z.; Chen, H.; Yang, Z.; Jiang, F. Decelerated coarsening of (Ti, Mo)C particles with a core-shell structure in austenite of a Ti-Mo-bearing steel. Metall. Mater. Trans. A 2018, 49, 1455-1459. [CrossRef]

63. Wang, Z.; Sun, X.; Yang, Z.; Yong, Q.; Zhang, C.; Li, Z.; Weng, Y. Carbide precipitation in austenite of aTi-Mo-containing low-carbon steel during stress relaxation. Mater. Sci. Eng. A 2013, 573, 84-91. [CrossRef]

64. Mohrbacher, H.; Sun, X.; Yong, Q.; Dong, H. MoNb-Based Alloying Concepts for Low-Carbon Bainitic Steels. In Advanced Steels; Weng, Y., Dong, H., Gan, Y., Eds.; Springer: Berlin/Heidelberg, Germany, 2011.

65. Funakawa, Y.; Seto, K. Coarsening behavior of nanometer-sized carbides in hot-rolled high strength sheet steel. Mater. Sci. Forum. 2007, 539-543, 4813-4818. [CrossRef]

66. Kim, Y.W.; Song, S.W.; Seo, S.J.; Hong, S.-G.; Lee, C.S. Development of Ti and Mo micro-alloyed hot-rolled high strength sheet steel by controlling thermomechanical controlled processing schedule. Mater. Sci. Eng. A 2013, 565, 430-438. [CrossRef]

67. Koldaev, A.V.; Zaitsev, A.I.; Krasnyanskaya, I.A.; D'yakonov, D.L. Study of the effect of composition and thermal deformation treatment on properties of ferritic steels microalloyed with titanium and niobium. Part 1. Microstructure characteristics. Metallurgist 2019, 63, 487-495. [CrossRef]

68. Larzabal, G.; Isasti, N.; Rodriguez-Ibabe, J.M.; Uranga, P. Evaluating strengthening and impact toughness mechanisms for ferritic and bainitic microstructures in Nb, Nb-Mo and Ti-Mo microalloyed steels. Metals 2017, 7, 65. [CrossRef]

69. Chen, C.Y.; Liao, M.H. Synergistic effects of carbon content and Ti/Mo ratio on precipitation behavior of HSLA steel: Insights from experiment and critical patent analysis. Mater. Des. 2020, 186, 108361. [CrossRef]

70. Rybkin, N.A.; Rodionova, I.G.; Shaposhnikov, N.G.; Kuznetsov, V.V.; Mishnev, P.A. Development of approaches for selecting the optimum alloying systems and production parameters for manufacturing hot-rolled high-strength low-alloy steels for automobile building. Metallurgist 2009, 53, 486-494. [CrossRef]

71. Sun, X.; Li, Z.; Huo, X.; Wang, Z. Physical metallurgy of titanium microalloyed steel—recrystallization and phase transformation. In Titanium Microalloyed Steel: Fundamentals, Technology, and Products; Mao, X., Ed.; Springer: Singapore, 2019; pp. 141-184. [CrossRef]

72. Lagneborg, R.; Zajac, S. A model for interphase precipitation in V-microalloyed structural steels. Metall. Mater. Trans. A 2001, 32, 39-50. [CrossRef]

73. Zajac, S. Precipitation of microalloy carbo-nitrides prior, during and after $\gamma / \alpha$ transformation. Mater. Sci. Forum. 2005, 500, 75-86. [CrossRef]

74. Echeverrı'a, A.; Rodriguez-Ibabe, J.M. The role of grain size in brittle particle induced fracture of steels. Mater. Sci. Eng. A 2003, 346, 149-158. [CrossRef]

75. Zhang, L.P.; Davis, C.L.; Strangwood, M. Effect of TiN particles and microstructure on fracture toughness in simulated heataffected zones of a structural steel. Metall. Mater. Trans. A 1999, 30, 2089-2096. [CrossRef] 
76. Liu, T.; Long, M.; Chen, D.; Duan, H.; Gui, L.; Yu, S.; Cao, J.; Chen, H.; Fan, H. Effect of coarse TiN inclusions and microstructure on impact toughness fluctuation in Ti micro-alloyed steel. J. Iron Steel Res. Int. 2018, 25, 1043-1053. [CrossRef]

77. Linaza, M.A.; Romero, J.L.; Rodríguez-Ibabe, J.M.; Urcola, J.J. Influence of the microstructure on the fracture toughness and fracture mechanisms of forging steels microalloyed with titanium with ferrite-pearlite structures. Scripta Metall. Mater. 1993, 29, 451-456. [CrossRef]

78. Sung, H.K.; Sohn, S.S.; Shin, S.Y.; Lee, S.; Kim, N.J.; Chon, S.H.; Yoo, J.Y. Effects of finish rolling temperature on inverse fracture occurring during drop weight tear test of API X80 pipeline steels. Mater. Sci. Eng. A 2012, 541, 181-189. [CrossRef]

79. Ji, F.; Li, C.; Tang, S.; Yuan, G.; Wang, G. Microstructural characteristics with various finish rolling temperature and low temperature toughness in hot rolled $\mathrm{Nb}-\mathrm{Ti}$ ferritic steel. ISIJ Int. 2016, 56, 602. [CrossRef] 